\title{
A cross-sectional analysis of dietary protein intake and body composition among Chinese Americans
}

\author{
Collin J. Popp ${ }^{1}$, Jeannette M. Beasley ${ }^{2}$, Stella S. Yi ${ }^{1}, \mathrm{Lu} \mathrm{Hu}^{1}$ and Judith Wylie-Rosett ${ }^{3}$ \\ ${ }^{1}$ Department of Population Health, NYU School of Medicine, New York, NY 10016, USA \\ ${ }^{2}$ Department of Medicine, NYU School of Medicine, New York, NY 10016, USA \\ ${ }^{3}$ Department of Epidemiology and Population Health, Albert Einstein College of Medicine, New York, NY 10461, USA
}

(Received 13 July 2018 - Final revision received 26 November 2018 - Accepted 6 December 2018 )

Journal of Nutritional Science (2019), vol. 8, e4, page 1 of 8

doi:10.1017/jns.2018.31

Abstract

Favourable body composition has been associated with higher dietary protein intake. However, little is known regarding this relationship in a population of Chinese Americans (CHA), who have lower BMI compared with other populations. The aim of the present study was to assess the relationship between dietary protein intake, fat mass (FM) and fat-free mass (FFM) in CHA. Data were from the Chinese American Cardiovascular Health Assessment (CHA CHA) 2010-2011 ( $n$ 1707); dietary intake was assessed using an adapted and validated FFQ. Body composition was assessed using bioelectrical impedance analysis. The associations between protein intake ( $\%$ energy intake) and BMI, percentage FM (FM\%), percentage FFM (FFM $\%)$, FM index (FMI) and FFM index (FFMI) were examined using multiple linear regression adjusted for age, sex, physical activity, acculturation, total energy intake, sedentary time, smoking status, education, employment and income. There was a significant positive association between dietary protein and BMI $(B=0.056,95 \%$ CI 0.017 , 0.104; $P=0.005), \mathrm{FM}(B=0.106,95 \% \mathrm{CI} 0.029,0 \cdot 184 ; P=0 \cdot 007), \mathrm{FM} \%(B=0 \cdot 112,95 \% \mathrm{CI} 0 \cdot 031,0 \cdot 194 ; P=0 \cdot 007)$ and $\mathrm{FMI}(B=0 \cdot 045,95 \% \mathrm{CI}$ $0.016,0.073 ; P=0.002)$. There was a significant negative association between dietary protein and FFM $\%(B=-0 \cdot 116,95 \% \mathrm{CI}-0 \cdot 196,-0 \cdot 036$; $P=0 \cdot 004)$. In conclusion, higher dietary protein intake was associated with higher adiposity; however, absolute FFM and FFMI were not associated with dietary protein intake. Future work examining the relationship between protein source (i.e. animal) and body composition is warranted in this population of CHA.

Key words: Lean body mass: Muscle mass: Percentage body fat: Adiposity: Obesity

Chinese Americans (CHA) represent the largest immigrant population in New York City. As of 2017 , the CHA population in New York City reached over 628000 individuals, a $76 \%$ increase over a 17 -year period ${ }^{(1)}$. The rapid growth of $\mathrm{CHA}$ draws health concerns as strong correlations exist between the length of US residency and increased prevalence of overweight, obesity and other non-communicable diseases ${ }^{(2-5)}$. The acculturative process is further complicated by the rapid increase of obesity and diabetes occurring currently in China $^{(6)}$, and how these patterns may be affecting newly arrived immigrant populations in the USA. CHA with obesity $(\geq 27 \cdot 5$ $\mathrm{kg} / \mathrm{m}^{2}$ ) are at four times greater risk of developing diabetes and high blood pressure compared with normal-BMI $\mathrm{CHA}^{(7)}$.

Body composition and metabolic risk vary across ethnic populations. Compared with Caucasian adults, Chinese adults experience higher odds of co-morbidities for a given BMI after adjusting for age and sex ${ }^{(8)}$. As such, modified ethnic-specific BMI cut-offs have been devised ${ }^{(9)}$. Chinese adults, on average, have lower BMI in comparison with Caucasian adults but higher adiposity stores $^{(10-12)}$. While BMI is useful for

* Corresponding author: Collin J. Popp, email collin.popp@nyumc.org

Abbreviations: \%EI, percentage energy intake; BIA, bioelectrical impedance analysis; BW, body weight; CHA, Chinese Americans; FFM, fat-free mass; FFM \%, percentage fatfree mass; FFMI, fat-free mass index; FM, fat mass; FM\%, percentage fat mass; FMI, fat mass index; PA, physical activity. 
evaluating body weight (BW) of individuals of different height, it falls short of providing an accurate index of body composition. Height-adjusted indexes for both fat mass (FM) and fatfree mass (FFM), called FM index (FMI) and FFM index (FFMI), respectively, provide a valid and more adequate representation of body composition ${ }^{(13)}$.

A lifestyle factor often promoted as a way to increase FFM is a high-protein diet. The Institutes of Medicine acceptable macronutrient distribution range (AMDR) of $10-35 \%$ of energy from protein covers a broad range of macronutrient needs depending on age, sex and activity level ${ }^{(14)}$. A higherprotein diet may exist on the higher end (20-25\% total energy intake) of this range. However, protein intake is traditionally defined in relative terms, with the recommended dietary allowance of $0.8 \mathrm{~g}$ protein $/ \mathrm{kg} \mathrm{BW}{ }^{(15)}$. A higher protein range of $1.2-1.8 \mathrm{~g} / \mathrm{kg} \mathrm{BW}$ is not uncommon in weight loss interventions and athletic populations. Protein intake has been found to have a greater thermic effect of food compared with carbohydrates and fats, leading to postprandial increases in energy expenditure $^{(16-18)}$. High-protein meals lead to greater satiety, which may lead to subsequent reductions in total energy intake $^{(19,20)}$. Furthermore, higher protein intake has been associated with lower BW, BMI and waist circumference ${ }^{(21)}$. Epidemiological evidence suggests that high protein intake is associated with higher FFM in adults and older adults ${ }^{(22-24)}$.

On average, US adults consume roughly $15 \%$ of their energy from dietary protein ${ }^{(25,26)}$. However, above-average protein levels (17-19\% of energy intake) of consumption have been reported in $\mathrm{CHA}^{(26-28)}$. Whether or not these higher levels contribute towards a more favourable body composition among this population has yet to be established. Little evidence exists assessing the relationship between dietary protein intake, FM and FFM in CHA. We hypothesised that higher dietary protein intake would be associated with higher levels of FFM and lower BMI in a cross-sectional sample of CHA immigrants living in New York City.

\section{Materials and methods}

\section{Study population}

The Chinese American Cardiovascular Health Assessment (CHA CHA; ClinicalTrials.gov identifier: NCT00362128) was a cross-sectional epidemiological survey conducted on immigrant CHA ( $n$ 2071) living in New York City ${ }^{(29-31)}$. Data collection occurred from 2010 to 2011. Screening and recruitment have been previously reported ${ }^{(31)}$. During the study visit anthropometrics, sociodemographic, acculturation and behavioural information were collected. All participants provided written informed consent. The Institutional Review Board of the Albert Einstein College of Medicine and the New York Downtown Hospital (now New York Presbyterian Hospital of Lower Manhattan) approved the study.

\section{Study instruments and covariates}

A Chinese-modified FFQ was used to assess reported total energy intake and macronutrient intake ${ }^{(32)}$. Participant data were excluded if total energy intake was $\leq 800$ or $\geq 4000 \mathrm{kcal} /$ $\mathrm{d}(\leq 3350$ or $\geq 16740 \mathrm{~kJ} / \mathrm{d})$ for males and $\leq 500$ or $\geq 3500$ $\mathrm{kcal} / \mathrm{d}$ ( $\leq 2090$ or $\geq 14640 \mathrm{~kJ} / \mathrm{d}$ ) for females. Macronutrients were reported as a percentage of total energy intake. In addition, protein was expressed as $\mathrm{g} / \mathrm{kg} \mathrm{BW}$ (g protein $/ \mathrm{kg}$ ) and $\mathrm{g} / \mathrm{kg}$ FFM (g protein/kg FFM). A validated Global Physical Activity Questionnaire (GPAQ) was used to measure physical activity $(\mathrm{PA})^{(33)}$. Participant data were excluded if reported PA exceeded $960 \mathrm{~min} / \mathrm{d}(16 \mathrm{~h} / \mathrm{d})$. Detailed descriptions of both the FFQ and GPAQ have previously been reported ${ }^{(29,31)}$. Questionnaires were presented in English with a Chinese translation below each question. The Stephenson Multigroup Acculturation Scale was used to measure acculturation, reported as ethnic society immersion and dominant society immer$\operatorname{sion}^{(34)}$. Questionnaires were used to record self-reported characteristics: age, sex, income, smoking status, education level and years living in New York City. Participants were divided into age categories: young (21-44 years old), middle-aged (45-64 years old) and older adults ( $\geq 65$ years old).

\section{Body composition}

Height, BW and body composition were measured during the clinical visit by trained examiners. Body composition was assessed in light indoor clothing using a foot-to-foot bioelectrical impendence analysis (BIA) (Tanita TBF300a). The foot-to-foot BIA method accurately predicts FFM in healthy Asian individuals ${ }^{(35)}$. BMI, FMI and FFMI were calculated by dividing absolute FM and FFM by height in metres squared $\left(\mathrm{kg} / \mathrm{m}^{2}\right)$, respectively. FFM includes all non-fat tissue. FM percentage (FM\%) and FFM percentage (FFM\%) were calculated by dividing by BW. Participants were divided into the $\mathrm{WHO}$ Asian BMI categories: underweight $\left(<18.5 \mathrm{~kg} / \mathrm{m}^{2}\right)$, normal weight $\left(18.5-22.9 \mathrm{~kg} / \mathrm{m}^{2}\right)$, overweight $\left(23.0-27.5 \mathrm{~kg} / \mathrm{m}^{2}\right)$ and obese $\left(\geq 27.5 \mathrm{~kg} / \mathrm{m}^{2}\right)^{(9)}$.

\section{Statistical analysis}

Mean and standard deviations were calculated for all variables except those in Table 3 where $95 \%$ CI were calculated. Sex-specific distributions were calculated for the body composition variables, and $t$ tests were used to calculate the differences between sexes. One-way ANOVA was used to determine the difference in body composition and dietary variables by WHO Asian BMI category and post hoc comparisons using Bonferroni's test. Two linear regression models were executed to determine associations between dependent variables (BW, BMI, FM, FMI, FM\%, FFM, FFMI, FFM\%) and the independent variables, protein intake as a percentage energy intake (\%EI) and absolute intake in $\mathrm{g} / \mathrm{d}$. We decided to express protein intake as $\% \mathrm{EI}$ in absolute intake, rather than relative to $\mathrm{BW}$ (g protein $/ \mathrm{kg} \mathrm{BW}$ ). Evaluating protein intake relative to $\mathrm{BW}$ as a predictor variable and body composition (e.g. FM, FFM) as the outcome variable would put mass on both sides of the equation. Therefore, analysing protein relative to BW would inflate the variance explained between relative protein and body composition. Expressing protein intake relative to energy intake should offer a more accurate 
Table 1. Participant characteristics, Cardiovascular Health Assessment in Chinese Americans (CHA CHA)

(Numbers of participants, percentages, mean values and standard deviations)

\begin{tabular}{|c|c|c|c|c|}
\hline & $n$ & $\%$ & Mean & SD \\
\hline Overall & 1707 & 100 & & \\
\hline Age (years) & 1707 & & $52 \cdot 9$ & 14.0 \\
\hline \multicolumn{5}{|l|}{ Age category* (years) } \\
\hline Young adult & 472 & & $35 \cdot 6$ & 6.9 \\
\hline Middle-age adult & 862 & & $54 \cdot 2$ & $5 \cdot 3$ \\
\hline Older adult & 373 & & 71.9 & $5 \cdot 3$ \\
\hline Female sex & 935 & $54 \cdot 8$ & & \\
\hline \multicolumn{5}{|l|}{ Smoking } \\
\hline Current smoker & 153 & $9 \cdot 0$ & & \\
\hline Former smoker & 394 & $23 \cdot 1$ & & \\
\hline \multicolumn{5}{|l|}{ PA } \\
\hline Total PA (min/week) & 1707 & & $375 \cdot 2$ & 334.1 \\
\hline Total moderate PA (min/week) & 1707 & & 344.4 & $306 \cdot 2$ \\
\hline Total vigorous PA (min/week) & 1707 & & 30.7 & $103 \cdot 0$ \\
\hline Sedentary time $(\min / \mathrm{d})$ & 1707 & & 328.6 & 174.7 \\
\hline \multicolumn{5}{|l|}{ Education } \\
\hline No school and elementary & 254 & 14.9 & & \\
\hline High school & 854 & $50 \cdot 0$ & & \\
\hline College and above & 599 & $35 \cdot 1$ & & \\
\hline \multicolumn{5}{|l|}{ Income } \\
\hline$\$ 0-9999$ & 558 & $32 \cdot 7$ & & \\
\hline$\$ 10000-19999$ & 513 & $30 \cdot 1$ & & \\
\hline$\$ 20000-29999$ & 289 & $16 \cdot 9$ & & \\
\hline$\$ 30000-49999$ & 198 & 11.6 & & \\
\hline$\$ 50000+$ & 149 & 8.7 & & \\
\hline \multicolumn{5}{|l|}{ Employment } \\
\hline Employed & 902 & $52 \cdot 8$ & & \\
\hline Unemployed & 197 & 11.5 & & \\
\hline Retired & 418 & 24.5 & & \\
\hline Housewife & 190 & $11 \cdot 1$ & & \\
\hline Time living in USA (years) & 1707 & & $13 \cdot 3$ & $10 \cdot 4$ \\
\hline Time living in New York City (years) & 1707 & & 12.5 & $10 \cdot 3$ \\
\hline \multicolumn{5}{|l|}{ Acculturation } \\
\hline ESI† & 1707 & & 3.64 & 0.2 \\
\hline DSI† & 1707 & & $2 \cdot 22$ & 0.6 \\
\hline
\end{tabular}

$\mathrm{PA}$, physical activity; ESI, ethnic society immersion; DSI, dominant society immersion.

* Young adult, 21-44 years; middle-aged adult, 45-64 years; older adult, 65+ years. † Scale range for ESI and DSI: $1-4$.

prediction of the contribution of protein to body composition. The first model included age, sex and PA (total moderate and total vigorous ( $\mathrm{min} /$ week)). The second model includes age, sex, PA, acculturation (ethnic society immersion, dominant society immersion), total energy intake, sedentary time, smoking status, education, employment and income. To adjust for energy intake, we used the nutrient density method, which includes both the nutrient as a proportion of energy intake and total energy intake in the model as described in Willett et al. ${ }^{(36)}$. Multicollinearity diagnostics were run with no indication among independent variables $(r<0 \cdot 80)$. However, there was strong correlation $(r 0.89$, variance inflation factor $=5.2)$ between energy intake and absolute protein intake. The level of significance was set at $P<0.05$. All statistical analyses were conducted using SPSS version 23 (IBM).

\section{Results}

The final sample included 1707 participants after excluding for $\mathrm{PA}$ values $>960 \mathrm{~min} / \mathrm{d}$ ( $n$ 299), and applying upper and lower total energy intake cut-offs $(n$ 65). The mean age was 52.9 (SD 14.0 ) years, and $54.8 \%$ were female (Table 1 ). The majority of participants had a high school $(50.0 \%)$ or college and above $(35.1 \%)$ education, and were employed $(52.8 \%) ; 8.7 \%$ of participants reported an annual household income over $\$ 50000$. Table 2 presents the dietary and anthropometric data tabulated together and separated by sex. The mean energy from dietary carbohydrate, protein and fat was 53.0 (SD 8.8), 19.0 (SD 3.4) and 28.2 (SD 6.0) \%, respectively. Comparing sexes, men consumed significantly greater total energy, $g$ of carbohydrates, $g$ of protein, $g$ of fat, saturated fat, monounsaturated fat and polyunsaturated fat compared with women $(P<0.05)$. There was no significant difference in $g$ of dietary fibre $(P=0.82)$ and relative protein $(\mathrm{g}$ protein $/ \mathrm{kg})(P=0.06)$ between sexes. The acculturation variables (ethnic society immersion and dominant society immersion) were not associated with percentage protein $(\% \mathrm{EI})$. Absolute protein $(\mathrm{g} / \mathrm{d})$ was weakly associated with dominant society immersion $(r 0 \cdot 102 ; P<0 \cdot 01)$.

The mean BMI for all participants was 23.9 (SD 3.2$) \mathrm{kg} / \mathrm{m}^{2}$, which falls within the overweight category for WHO Asian BMI cut-offs ${ }^{(9)}$. FFM, FM\% and FFMI were significantly higher in males compared with females $(P<0 \cdot 0001)$, whereas the opposite was true regarding FM, FM\% and FMI $(P<$ 0.0001). Participants who were overweight or obese had higher FM whether expressed as $\mathrm{kg}, \%$ or $\mathrm{kg} / \mathrm{m}^{2}$ and higher absolute FFM $(\mathrm{kg})$ but lower relative FFM $\left(\%\right.$ or $\left.\mathrm{kg} / \mathrm{m}^{2}\right)$ compared with participants classified as underweight or normal weight (Supplementary Table S1).

There was no significant difference among BMI categories for total energy intake, carbohydrates, protein and fat (Supplementary Table S1). There was no difference between relative protein $(\mathrm{g} / \mathrm{d})$ intake by BMI category (Fig. 1(A)), but participants in the underweight and normal-weight BMI categories consumed significantly more relative protein (g protein $/ \mathrm{kg}$ ) than those in the overweight and obese BMI categories (Fig. 1(B)). Adjusting for protein intake relative to FFM (g protein/kg FFM), participants in the underweight BMI category did not differ from all other groups. However, those in the normal-weight BMI category had significantly greater protein intake relative to FFM (g protein $/ \mathrm{kg}$ FFM) compared with the overweight and obese categories (Fig. 1(C)). Protein intake stratified by age category indicates that younger adults consumed more absolute $(\mathrm{g} / \mathrm{d})$ and relative protein (g protein $/ \mathrm{kg}$ and $\mathrm{g}$ protein $/ \mathrm{kg}$ FFM) compared with middleaged and older adults (Supplementary Table S2).

After adjusting for covariates, there was a significant positive association between protein (\%EI) and BMI $(B=0.056,95 \%$ CI $0.017,0 \cdot 104 ; P=0 \cdot 005), F M(B=0.106,95 \%$ CI 0.029 , $0 \cdot 184 ; P=0 \cdot 007), \mathrm{FM} \%(B=0.112,95 \%$ CI $0.031,0 \cdot 194$; $P=0.007)$ and FMI $(B=0.045,95 \%$ CI $0.016,0.073 ; P=$ 0.002 ) (Table 3). There was a significant negative association between protein $(\% \mathrm{EI})$ and $\mathrm{FFM} \%(B=-0 \cdot 116,95 \% \mathrm{CI}$ $-0.196,-0.036 ; P=0.004)$. However, absolute FFM and FFMI were not significantly associated with percentage protein ( $B=0.026,95 \% \mathrm{CI}-0.040,0.092, P=0.435 ; B=0.02,95 \%$ CI $-0.03,0.037, P=0.087)$. A similar relationship among all body composition variables occurred when protein was 
Table 2. Energy intake and body composition by sex (Mean values and standard deviations)

\begin{tabular}{|c|c|c|c|c|c|c|c|}
\hline & \multicolumn{2}{|c|}{ Total ( $n$ 1707) } & \multicolumn{2}{|c|}{ Male $(n 772)$} & \multicolumn{2}{|c|}{ Female ( $n$ 935) } & \multirow[b]{2}{*}{$P: \mathrm{M} v . \mathrm{F}$} \\
\hline & Mean & SD & Mean & SD & Mean & SD & \\
\hline Energy intake & & & & & & & $<0.0001$ \\
\hline $\mathrm{kcal} / \mathrm{d}$ & $1739 \cdot 8$ & 636.6 & $1900 \cdot 5$ & 651.4 & $1607 \cdot 0$ & 592.4 & \\
\hline $\mathrm{kJ} / \mathrm{d}$ & $7279 \cdot 3$ & 2663.5 & $7951 \cdot 7$ & 2725.5 & 6723.7 & $2478 \cdot 6$ & \\
\hline Carbohydrates (g/d) & $227 \cdot 7$ & 84.3 & $249 \cdot 6$ & $87 \cdot 2$ & 209.5 & $77 \cdot 2$ & $<0.0001$ \\
\hline Dietary fibre $(\mathrm{g} / \mathrm{d})$ & $20 \cdot 6$ & 9.4 & $20 \cdot 7$ & 9.4 & $20 \cdot 6$ & $9 \cdot 3$ & 0.82 \\
\hline Protein $(g / d)$ & $83 \cdot 3$ & 35.8 & $90 \cdot 4$ & $37 \cdot 6$ & 77.4 & 33.3 & $<0.0001$ \\
\hline Protein (g/kg BW per d) & 1.34 & 0.59 & 1.31 & 0.56 & 1.36 & 0.61 & 0.06 \\
\hline Protein (g/kg FFM per d) & 1.78 & 0.77 & 1.64 & 0.68 & 1.90 & 0.82 & $<0.0001$ \\
\hline Fat $(g / d)$ & 55.5 & $26 \cdot 0$ & 58.8 & $27 \cdot 3$ & $52 \cdot 7$ & 24.6 & $<0.0001$ \\
\hline $\operatorname{SFA}(g / d)$ & $16 \cdot 2$ & $8 \cdot 2$ & $17 \cdot 3$ & 8.6 & $15 \cdot 3$ & $7 \cdot 6$ & $<0.0001$ \\
\hline MUFA (g/d) & $20 \cdot 8$ & $10 \cdot 0$ & $22 \cdot 3$ & $10 \cdot 5$ & $19 \cdot 6$ & 9.4 & $<0.0001$ \\
\hline PUFA (g/d) & 14.0 & $7 \cdot 2$ & 14.5 & 7.4 & 13.5 & 6.9 & 0.004 \\
\hline Height (cm) & $162 \cdot 3$ & 8.5 & 168.5 & $6 \cdot 6$ & $157 \cdot 3$ & $6 \cdot 2$ & $<0.0001$ \\
\hline BW (kg) & 63.1 & 11.0 & 69.9 & $10 \cdot 1$ & 57.6 & $8 \cdot 2$ & $<0.0001$ \\
\hline BMI $\left(\mathrm{kg} / \mathrm{m}^{2}\right)$ & 23.9 & $3 \cdot 2$ & $24 \cdot 6$ & $3 \cdot 2$ & $23 \cdot 3$ & & $<0.0001$ \\
\hline Waist (cm) & 83.1 & $9 \cdot 1$ & $86 \cdot 3$ & 8.4 & $80 \cdot 4$ & 8.9 & $<0.0001$ \\
\hline FFM (kg) & 47.5 & 8.7 & 55.4 & 6.4 & $41 \cdot 0$ & 3.4 & $<0.0001$ \\
\hline FFM\% & $75 \cdot 5$ & $7 \cdot 2$ & $79 \cdot 8$ & $5 \cdot 2$ & 71.9 & $6 \cdot 7$ & $<0.0001$ \\
\hline FFMI $\left(\mathrm{kg} / \mathrm{m}^{2}\right)$ & $17 \cdot 9$ & $2 \cdot 0$ & 19.5 & 1.6 & $16 \cdot 6$ & $1 \cdot 2$ & $<0.0001$ \\
\hline FM (kg) & $15 \cdot 6$ & $5 \cdot 8$ & 14.5 & $5 \cdot 2$ & $16 \cdot 6$ & $6 \cdot 0$ & $<0.0001$ \\
\hline FM\% & 24.5 & $7 \cdot 3$ & $20 \cdot 2$ & $5 \cdot 2$ & $28 \cdot 1$ & $6 \cdot 9$ & $<0.0001$ \\
\hline FMI $\left(\mathrm{kg} / \mathrm{m}^{2}\right)$ & $6 \cdot 0$ & $2 \cdot 3$ & $5 \cdot 1$ & $1 \cdot 8$ & $6 \cdot 7$ & 2.4 & $<0.0001$ \\
\hline
\end{tabular}

M v. F, male $v$. female; BW, body weight; FFM, fat-free mass; FFM\%, fat-free mass as a percentage of total body weight; FFMI, fat-free mass index; FM, fat mass; FM\%, fat mass as a percentage of total body weight; FMI, fat mass index.

expressed in absolute terms $(\mathrm{g} / \mathrm{d})$, except there was no significant relationship between BW and absolute protein intake for both model 1 and model 2 .

\section{Discussion}

Our study, which examined the relationship between dietary protein intake and body composition measures (FM and FFM), found that in immigrant CHA ( $n$ 1707), higher dietary protein intake as a percentage of energy intake was associated with higher adiposity. Contrary to our hypothesis, our results demonstrate that percentage protein $(\% \mathrm{EI})$ was inversely associated with FFM $\%$. However, absolute FFM and height-adjusted FFM (FFMI) were not associated with dietary protein intake. FFMI is a better indicator of non-fat tissue, accounting for differences in height within a population ${ }^{(37)}$. These results suggest that above-average intake of dietary protein as a percentage of total energy intake does not equate to higher levels of FFM in CHA.

In this cross-sectional analysis, higher protein intake was associated with higher BMI, FM and FMI after adjusting for covariates. Dietary protein, unlike dietary fat and carbohydrates, is not stored for the purpose of energy production. Under normal conditions the assimilation of amino acids from dietary protein into fatty acids to be stored in adipose tissue is unlikely. Under abnormal conditions, as with hyperenergetic feeding, protein intake $(20-25 \% \mathrm{EI})$ on the higher end of the acceptable macronutrient distribution range (AMDR) leads to minimal increases in FM among sedentary individuals ${ }^{(38,39)}$. Considering the majority of our population were active ( $>150 \mathrm{~min} /$ week of moderate-to-vigorous PA), the likelihood of energy from dietary protein contributing substantially to excess adiposity seems low.
Instead, the source of dietary protein (animal $v$. plant) may contribute to the positive association with BMI and FM. This sample may have consumed more animal protein, as we found protein intake to be positively associated with fat intake $(r 0.64 ; P<0.05)$ and inversely associated with carbohydrate intake $(r-0.85 ; P<0.01)$. Plant proteins are often lower in dietary fat and higher in carbohydrates, especially dietary fibre, which may modulate the diversity of gut microbiota affecting body composition ${ }^{(40)}$. Evidence from Chinese adults who underwent physical performance and appendicular skeletal muscle (ASM) assessment 4 years apart found no association between ASM and relative protein intake. However, participants in the highest quartile of relative vegetable protein lost significantly less ASM over 4 years $^{(41)}$.

CHA may be consuming fewer lean sources of animal protein or consuming protein-containing dishes with added sources of fats (i.e. cooking oils). Animal sources provide both SFA and unsaturated fatty acids; we found protein intake to be significantly correlated with saturated fat $(r$ 0.408; $P<0.0001)$ and monounsaturated fat $(r 0.401 ; P<0.0001)$. These positive relationships may result in the protein sources providing additional energy from dietary fat, which may lead to the propensity to gain weight.

The propensity of CHA to consume more dietary protein may be driven by acculturative stress. As opposed to a 'Westernisation of diet', increased consumption of traditional 'festival foods' (high in carbohydrates, animal protein, sugar and fat) among immigrants has been described as an explanatory factor in increased cardiometabolic risk in these populations ${ }^{(42)}$. Due to acculturative stress, immigrants may seek these foods as a source of comfort and maintenance of ethnic 

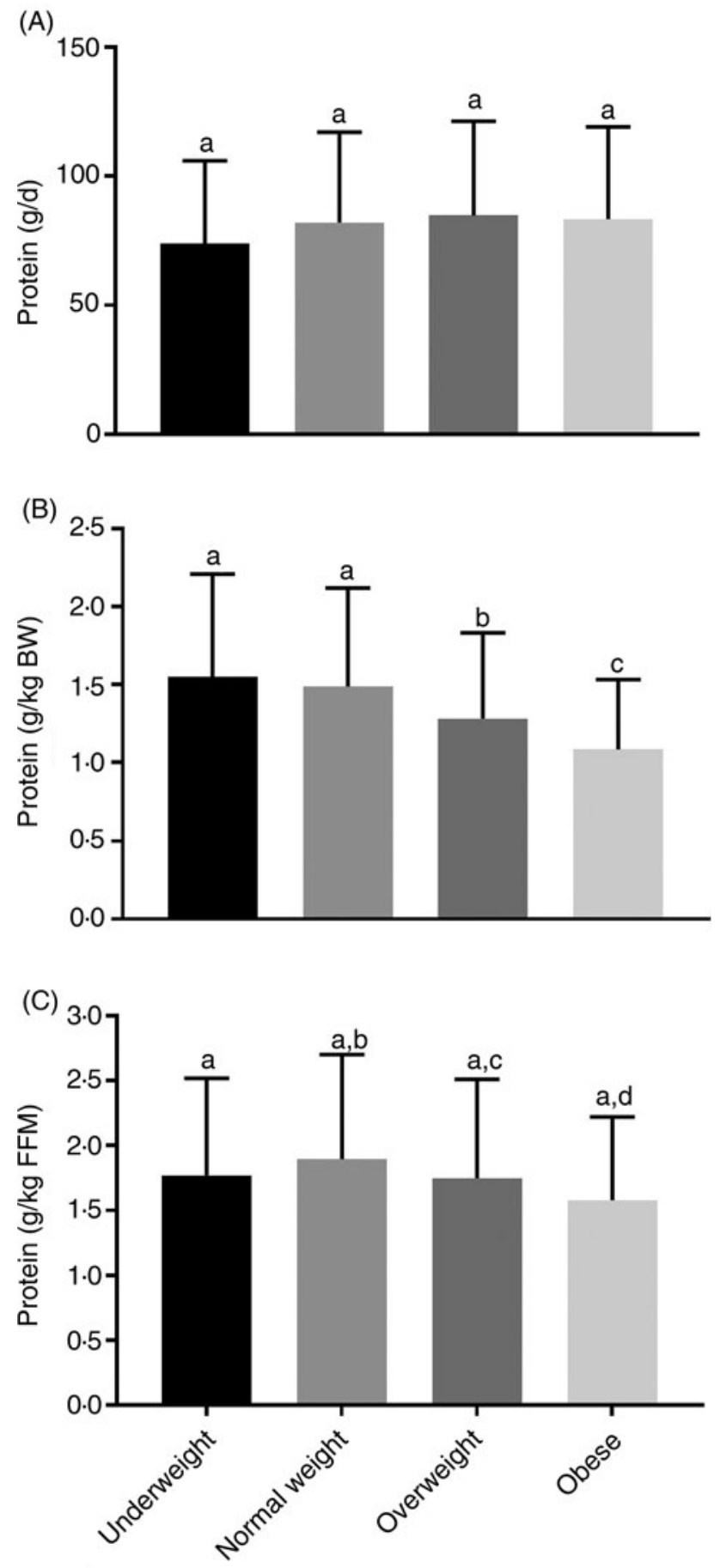

Fig. 1. Dietary protein by BMl category. Relative protein intake (g protein/d) (A) was not significantly different across all BMI categories. Adjusting for body weight $(\mathrm{BW})(\mathrm{B})$, underweight and normal-weight $\mathrm{BMl}$ categories had significantly greater relative dietary protein compared with overweight and obese BMI categories. Adjusting relative to fat-free mass (FFM) (C), normal-weight participants had significantly greater protein intake than overweight and obese participants. Underweight, $n$ 59; normal weight, $n$ 633; overweight, $n$ 803; obese, $n$ 214. Values are means, with standard deviations represented by vertical bars. ${ }^{a, b, c, d}$ Mean values with unlike letters were significantly different $(P<0.05)$.

identity. However, adjusting for acculturation in our model was not associated with adiposity or FFM indices.

As aforementioned, US adults consume roughly $15 \%$ of their energy from dietary protein ${ }^{(25,26)}$. Our results confirm previous evidence that $\mathrm{CHA}$ consume more protein compared with the general population. Recent data from the National Health and Nutrition Examination Survey (NHANES) 2011-2014 indicate that Asian adults (Chinese not specified) consumed roughly $17 \%$ of energy intake from protein ${ }^{(25)}$. Nettleton et al. ${ }^{(27)}$ reported $17.7 \%$ energy through a modified block-style 120-item FFQ intake from protein from a sample of CHA, and numbers adapted from Wong et al. ${ }^{(28)}$ were estimated to be around $19.2 \%$ of energy intake from protein using three 24-h recalls in a sample of older CHA $>50$ years old). In contrast, lower percentages have been reported in Chinese adults living in China. Stookey ${ }^{(43)}$ reported $12 \%$ energy intake from protein using multiple 24-h recalls, and Lee et al. ${ }^{(44)}$ reported only $9 \%$ energy intake from protein using an eighty-four-question FFQ in adults living in China.

Categorising the groups by BMI, absolute protein revealed no difference among the four BMI categories. Underweight and normal-weight groups consumed significantly more relative protein ( $\mathrm{g}$ protein $/ \mathrm{kg}$ ) than adults in the overweight and obese groups. This may be attributed to under-reporting, common amongst adults with obesity ${ }^{(45)}$; however, the more likely reason is the higher body mass in both the overweight and obese groups. Further adjusting of protein relative to FFM (kg) abolished the difference between underweight, overweight and obese adults. However, we found that normal-weight participants consumed significantly more protein/ $\mathrm{kg}$ FFM than both overweight and obese adults. Grouping by age category, younger adults in this CHA population consumed significantly more absolute $(\mathrm{g} / \mathrm{d}$ ) and relative protein ( $\mathrm{g}$ protein/ $\mathrm{kg}$ and $\mathrm{g}$ protein/kg FFM). Age-related declines in energy intake, and especially protein intake, are common. Recent research suggests that older adults may need to consume greater amounts $(>0.8 \mathrm{~g}$ protein $/ \mathrm{kg})$ of protein to maintain and prevent muscle mass loss ${ }^{(46,47)}$.

The strengths of our study included a large sample, the inclusion of both sexes, and a comprehensive definition of body composition of an immigrant population. While our study found a positive relationship between dietary protein and body adiposity in CHA, there were some limitations. FFQ are useful for assessing diet-health relationships, providing information on long-term dietary intake and are commonly used in nutrition epidemiology. Unfortunately, they are not intended for the purpose of estimating energy intake as they may lack detail, are dependent on the number of items and may be affected by the recent $\operatorname{diet}^{(48)}$. Tseng \& Hernández ${ }^{(32)}$ found a moderate correlation $(r 0 \cdot 30)$ between the FFQ used in this study and three $24 \mathrm{~h}$ recalls in a small sample of US Chinese women. Furthermore, the crosssectional nature of the study only allows for conclusions between dietary protein and body composition to be associative and not causal. The relationship between body composition variables and absolute protein intake $(\mathrm{g} / \mathrm{d})$ should be interpreted with caution as evidence by collinearity between energy intake and absolute protein. Lastly, body composition assessment by BIA is not the 'gold standard' measure, nor does BIA provide a regional distribution of body adiposity. Using skin-fold callipers to assess body composition, Wang et al. ${ }^{(1)}$ found that that Asians (the majority Chinese) had more subcutaneous fat in the upper body (e.g. shoulders, 
Table 3. Association between protein intake and body composition $\dagger$

\begin{tabular}{|c|c|c|c|c|c|c|c|c|}
\hline & \multicolumn{4}{|c|}{ Protein (\%El) } & \multicolumn{4}{|c|}{ Protein (g/d) } \\
\hline & $B$ & $95 \% \mathrm{Cl}$ & $\beta$ & $P$ & $B$ & $95 \% \mathrm{Cl}$ & $\beta$ & $P$ \\
\hline \multicolumn{9}{|c|}{ Body weight $(\mathrm{kg})$} \\
\hline Model 1 & 0.123 & $-0.005,0.251$ & 0.038 & 0.06 & 0.021 & $-0.007,0.049$ & 0.069 & 0.135 \\
\hline Model 2 & 0.132 & $0.004,0.260$ & 0.041 & $0.043^{\star}$ & 0.023 & $-0.005,0.050$ & 0.073 & 0.109 \\
\hline \multicolumn{9}{|c|}{ BMI $\left(\mathrm{kg} / \mathrm{m}^{2}\right)$} \\
\hline Model 1 & 0.056 & $0.012,0.100$ & 0.060 & $0.012^{*}$ & 0.011 & $0.002,0.021$ & 0.123 & $0.022^{*}$ \\
\hline Model 2 & 0.060 & $0.017,0.104$ & 0.064 & $0.005^{\star *}$ & 0.011 & $0.002,0.021$ & 0.127 & $0.017^{*}$ \\
\hline \multicolumn{9}{|l|}{ FM (kg) } \\
\hline Model 1 & 0.099 & $0.021,0.176$ & 0.059 & $0.013^{\star}$ & 0.017 & $0.001,0.034$ & 0.108 & $0.042^{*}$ \\
\hline Model 2 & 0.106 & $0.029,0.184$ & 0.063 & $0.007^{* *}$ & 0.018 & $0.002,0.035$ & 0.115 & $0.031^{*}$ \\
\hline \multicolumn{9}{|l|}{ FM\% } \\
\hline Model 1 & 0.103 & $0.021,0.184$ & 0.048 & $0.014^{*}$ & 0.019 & $0.002,0.037$ & 0.094 & $0.032^{*}$ \\
\hline Model 2 & 0.112 & $0.031,0.194$ & 0.052 & $0.007^{\star \star}$ & 0.021 & $0.003,0.038$ & $0 \cdot 101$ & $0.022^{*}$ \\
\hline \multicolumn{9}{|l|}{$\mathrm{FMl}\left(\mathrm{kg} / \mathrm{m}^{2}\right)$} \\
\hline Model 1 & 0.041 & $0.012,0.070$ & 0.062 & $0.005^{* *}$ & 0.008 & $0.001,0.014$ & 0.120 & $0.016^{*}$ \\
\hline Model 2 & 0.045 & $0.016,0.073$ & 0.067 & $0.002^{* *}$ & 0.008 & $0.002,0.014$ & 0.126 & $0.011^{*}$ \\
\hline \multicolumn{9}{|l|}{ FFM (kg) } \\
\hline Model 1 & 0.025 & $-0.041,0.091$ & 0.010 & 0.457 & 0.004 & $-0.01,0.018$ & 0.016 & 0.602 \\
\hline Model 2 & 0.026 & $-0.040,0.092$ & 0.010 & 0.435 & 0.004 & $-0.010,0.018$ & 0.017 & 0.559 \\
\hline \multicolumn{9}{|l|}{ FFM\% } \\
\hline Model 1 & -0.106 & $-0.186,-0.026$ & -0.050 & $0.009^{\star *}$ & -0.02 & $-0.037,-0.003$ & $-0 \cdot 10$ & $0.021^{*}$ \\
\hline Model 2 & -0.116 & $-0.196,-0.036$ & -0.055 & $0.004^{* *}$ & -0.022 & $-0.039,0.004$ & -0.107 & $0.014^{*}$ \\
\hline \multicolumn{9}{|c|}{ FFMI $\left(\mathrm{kg} / \mathrm{m}^{2}\right)$} \\
\hline Model 1 & 0.017 & $-0.003,0.037$ & 0.028 & $0.01^{*}$ & 0.004 & $0.000,0.008$ & 0.069 & 0.074 \\
\hline Model 2 & 0.02 & $-0.03,0.037$ & 0.03 & 0.087 & 0.004 & $0.00,0.08$ & 0.070 & 0.072 \\
\hline
\end{tabular}

$\% \mathrm{El}$, percentage energy intake; $B$, unstandardised regression coefficient; $\beta$, standardised regression coefficient; FM, fat mass; FM\%, fat mass as a percentage of total body weight; FMI, fat mass index; FFM, fat-free mass; FFM\%, fat-free mass as a percentage of total body weight; FFMI, fat-free mass index; ESI, ethnic society immersion; DSI, dominant society immersion.

${ }^{*} P<0.05,{ }^{* *} P<0.001$.

† Model 1: age, sex, physical activity; model 2: model 1 plus acculturation (ESI, DSI), total energy intake, sedentary time, smoking status, education, employment and income.

biceps) and trunk than Caucasians. Regional changes in body composition may play a larger metabolic role rather than total body composition ${ }^{(49)}$. Despite these limitations, we believe that these results provide useful context between dietary intake and body composition among CHA immigrants.

In this population of $\mathrm{CHA}$, dietary protein was associated with higher adiposity, specifically BMI and FMI, even after adjusting for covariates. Younger adults consumed significantly more absolute and relative protein compared with middle-aged and older adults. Contrary to our hypothesis, dietary protein was not associated with FFM and FFMI. Future research could employ more accurate measures of dietary intake (e.g. 24-h recalls) with 'gold standard' tools of body composition, or examine how sources of dietary protein may modify the effect of protein intake on body composition.

\section{Supplementary material}

The supplementary material for this article can be found at https://doi.org/10.1017/jns.2018.31

\section{Acknowledgements}

The authors would like to thank all of the participants who volunteered for the study.

This research was supported in part by funding from the American Heart Association and National Institutes of Health (NIH) grants R01HL077809, UL1 RR025750, P30DK111022, P60MD000538 from the NIH National
Institute on Minority Health and Health Disparities, U48DP005008 from the Centers for Disease Control and Prevention (CDC) and UL1TR001445 from the National Center for Advancing Translational Sciences (NCATS)/NIH. The NIH and CDC had no role in the design, analysis or writing of this article.

The authors' contributions are as follows: C. J. P. analysed the data and wrote the paper; J. M. B. oversaw the development and design, assisted with the statistical analysis and wrote the paper; L. H. assisted with the statistical analysis and writing of the paper; S. S. Y. assisted with the analysis of the PA variables and writing of the paper; J. W.-R. designed and conducted research, provided essential reagents and assisted with the writing of the paper. All authors read and approved the final paper.

C. J. P. is a sport nutrition consultant for Renaissance Periodization, LLC. The authors have no financial conflicts of interest to declare.

\section{References}

1. United States Census Bureau (2018) American Community Survey (ACS). 2017 ACS 1-Year Estimates, Table S0201. https:// factfinder. census.gov/faces/tableservices/jsf/pages/productview.xhtml?pid= ACS_17_1YR_S0201\&prodType=table (accessed January 2019).

2. Gong $Z \&$ \& hao D (2016) Cardiovascular diseases and risk factors among Chinese immigrants. Intern Emerg Med 11, 307-318.

3. Park Y, Neckerman KM, Quinn J, et al. (2008) Place of birth, duration of residence, neighborhood immigrant composition and body mass index in New York City. Int J Behav Nutr Phys Act 5, 19. 
4. Sanchez-Vaznaugh EV, Kawachi I, Subramanian SV, et al. (2008) Differential effect of birthplace and length of residence on body mass index (BMI) by education, gender and race/ethnicity. Soc S $i$ Med 67, 1300-1310.

5. Yeh MC, Fahs M, Shelley D, et al. (2009) Body weight and length of residence in the US among Chinese Americans. J Immigr Minor Health 11, 422-427.

6. Hu FB (2011) Globalization of diabetes: the role of diet, lifestyle, and genes. Diabetes Care 34, 1249-1257.

7. Kwon SC, Wyatt LC, Li S, et al. (2017) Obesity and modifiable cardiovascular disease risk factors among Chinese Americans in New York City, 2009-2012. Prev Chronic Dis 14, 160582.

8. He W, Li Q, Yang M, et al. (2015) Lower BMI cutoffs to define overweight and obesity in China. Obesity 23, 684-691.

9. WHO Expert Consultation (2004) Appropriate body-mass index for Asian populations and its implications for policy and intervention strategies. Lancet 363, 157-163.

10. Wang J, Rennie KL, Gu W, et al. (2009) Independent associations of body-size adjusted fat mass and fat-free mass with the metabolic syndrome in Chinese. Ann Hum Biol 36, 110-121.

11. Wang J, Thornton JC, Russell M, et al. (1994) Asians have lower body mass index (BMI) but higher percent body fat than do whites: comparisons of anthropometric measurements. Am J Clin Nutr 60, 23-28.

12. Deurenberg P, Yap M \& van Staveren WA (1998) Body mass index and percent body fat: a meta analysis among different ethnic groups. Int J Obes Relat Metab Disord 22, 1164-1171.

13. VanItallie TB, Yang MU, Heymsfield SB, et al. (1990) Height-normalized indices of the body's fat-free mass and fat mass: potentially useful indicators of nutritional status. $A m J$ Clin Nutr 52, 953-959.

14. Manore MM (2005) Exercise and the Institute of Medicine recommendations for nutrition. Curr Sports Med Rep 4, 193-198.

15. Wycherley TP, Moran LJ, Clifton PM, et al. (2012) Effects of energy-restricted high-protein, low-fat compared with standardprotein, low-fat diets: a meta-analysis of randomized controlled trials. Am J Clin Nutr 96, 1281-1298.

16. Karst H, Steiniger J, Noack R, et al. (1984) Diet-induced thermogenesis in man: thermic effects of single proteins, carbohydrates and fats depending on their energy amount. Ann Nutr Metab 28, 245-252.

17. Crovetti R, Porrini M, Santangelo A, et al. (1998) The influence of thermic effect of food on satiety. Eur J Clin Nutr 52, 482-488.

18. Dauncey MJ \& Bingham SA (1983) Dependence of 24 h energy expenditure in man on the composition of the nutrient intake. $\mathrm{Br}$ J Nutr 50, 1-13.

19. Westerterp-Plantenga MS, Rolland V, Wilson SA, et al. (1999) Satiety related to $24 \mathrm{~h}$ diet-induced thermogenesis during high protein/carbohydrate vs high fat diets measured in a respiration chamber. Eur J Clin Nutr 53, 495-502.

20. Foster-Schubert KE, Overduin J, Prudom CE, et al. (2008) Acyl and total ghrelin are suppressed strongly by ingested proteins, weakly by lipids, and biphasically by carbohydrates. J Clin Endocrinol Metab 93, 1971-1979.

21. Aller EEJG, Larsen TM, Claus H, et al. (2014) Weight loss maintenance in overweight subjects on ad libitum diets with high or low protein content and glycemic index: the DIOGENES trial 12-month results. Int J Obes 38, 1511-1517.

22. Sahni S, Mangano KM, Hannan MT, et al. (2015) Higher protein intake is associated with higher lean mass and quadriceps muscle strength in adult men and women. J Nutr 145, 1569-1575.

23. Gregorio L, Brindisi J, Kleppinger A, et al. (2014) Adequate dietary protein is associated with better physical performance among post-menopausal women 60-90 years. J Nutr Health Aging 18, 155-160.

24. Mangano KM, Sahni S, Kiel DP, et al. (2017) Dietary protein is associated with musculoskeletal health independently of dietary pattern: the Framingham Third Generation Study. Am J Clin Nutr 105, $714-722$.
25. Berryman CE, Lieberman HR, Fulgoni VL III, et al. (2018) Protein intake trends and conformity with the Dietary Reference Intakes in the United States: analysis of the National Health and Nutrition Examination Survey, 2001-2014. Am J Clin Nutr 108, 405-413.

26. National Center for Health Statistics (2017) Health, United States, 2016. With Chartbook on Long-term Trends in Health. Hyattsville, MD: Centers for Disease Control and Prevention. https://www.cdc.gov/nchs/data/hus/hus16.pdf (accessed January 2019).

27. Nettleton JA, Rock CL, Wang Y, et al. (2009) Associations between dietary macronutrient intake and plasma lipids demonstrate criterion performance of the Multi-Ethnic Study of Atherosclerosis (MESA) food-frequency questionnaire. Br J Nutr 102, 1220-1227.

28. Wong SS, Beth Dixon L, Gilbride JA, et al. (2011) Diet, physical activity, and cardiovascular disease risk factors among older Chinese Americans living in New York City. J Community Health 36, 446-455.

29. Afable A, Yeh MC, Trivedi T, et al. (2016) Duration of US residence and obesity risk in NYC Chinese immigrants. I Immigr Minor Health 18, 624-635.

30. Rajpathak SN \& Wylie-Rosett J (2011) High prevalence of diabetes and impaired fasting glucose among Chinese immigrants in New York City. J Immigr Minor Health 13, 181-183.

31. Yi SS, Beasley JM, Kwon SC, et al. (2016) Acculturation and activity behaviors in Chinese American immigrants in New York City. Prev Med Rep 4, 404-409.

32. Tseng M \& Hernández $\mathrm{T}$ (2005) Comparison of intakes of US Chinese women based on food frequency and 24-hour recall data. J Am Diet Assoc 105, 1145-1148.

33. Cleland CL, Hunter RF, Kee F, et al. (2014) Validity of the Global Physical Activity Questionnaire (GPAQ) in assessing levels and change in moderate-vigorous physical activity and sedentary behaviour. $B M C$ Public Health 14, 1255.

34. Stephenson M (2000) Development and validation of the Stephenson Multigroup Acculturation Scale (SMAS). Psychol Assess 12, 77-88.

35. Wu C-S, Chen Y-Y, Chuang C-L, et al. (2015) Predicting body composition using foot-to-foot bioelectrical impedance analysis in healthy Asian individuals. Nutr J 14, 52.

36. Willett WC, Howe GR \& Kushi LH (1997) Adjustment for total energy intake in epidemiologic studies. Am J Clin Nutr 65, 1220S-1228S; discussion 1229S-1231S.

37. Lu Y, Shu H, Zheng Y, et al. (2012) Comparison of fat-free mass index and fat mass index in Chinese adults. Eur J Clin Nutr 66, 1004-1007.

38. Webb P \& Annis JF (1983) Adaptation to overeating in lean and overweight men and women. Hum Nutr Clin Nutr 37, 117-131.

39. Bray GA, Smith SR, de Jonge L, et al. (2012) Effect of dietary protein content on weight gain, energy expenditure, and body composition during overeating: a randomized controlled trial. JAMA 307, $47-55$.

40. Mayorga Reyes L, González Vázquez R, Cruz Arroyo SM, et al. (2016) Correlation between diet and gut bacteria in a population of young adults. Int J Food Sci Nutr 67, 470-478.

41. Chan R, Leung J, Woo J, et al. (2014) Associations of dietary protein intake on subsequent decline in muscle mass and physical functions over four years in ambulant older Chinese people. J Nutr Health Aging 18, 171-177.

42. Azar KMJ, Chen E, Holland AT, et al. (2013) Festival foods in the immigrant diet. J Immigr Minor Health 15, 953-960.

43. Stookey J (2001) Energy density, energy intake and weight status in a large free-living sample of Chinese adults: exploring the underlying roles of fat, protein, carbohydrate, fiber and water intakes. Eur J Clin Nutr 55, 349-359.

44. Lee MM, Wu-Williams A, Whittemore AS, et al. (1994) Comparison of dietary habits, physical activity and body size among Chinese in North America and China. Int J Epidemiol 23, 984-990.

45. Karelis AD, Lavoie M-E, Fontaine J, et al. (2010) Anthropometric, metabolic, dietary and psychosocial profiles of underreporters of 
energy intake: a doubly labeled water study among overweight/ obese postmenopausal women - a Montreal Ottawa New Emerging Team study. Eur J Clin Nutr 64, 68-74.

46. McLean RR, Mangano KM, Hannan MT, et al. (2016) Dietary protein intake is protective against loss of grip strength among older adults in the Framingham Offspring Cohort. J Gerontol A Biol Sci Med Sci 71, 356-361.

47. Traylor DA, Gorissen SHM \& Phillips SM (2018) Perspective: protein requirements and optimal intakes in aging: are we ready to recommend more than the recommended daily allowance? $A d v$ Nutr 9, 171-182.

48. Subar AF, Freedman LS, Tooze JA, et al. (2015) Addressing current criticism regarding the value of self-report dietary data. J Nutr 145, $2639-2645$.

49. Tang M, Leidy HJ \& Campbell WW (2013) Regional, but not total, body composition changes in overweight and obese adults consuming a higher protein, energy-restricted diet are sex specific. Nutr Res 33, 629-635. 